\title{
Mülteci Temsillerinde Kültürel Farklılık İnşası ve Toplumsal Kabule Etkileri* $^{*}$
}

\section{The Construction of Cultural Difference in Refugee Representations and its Implications for Social Acceptance}

\author{
Dr. Öğr. Üyesi Müzeyyen PANDIR (iD) 1
}

\begin{abstract}
$\ddot{\mathbf{O z}}$
Türk toplumu ve Suriyeli mülteciler arasında toplumsal kabul ve uyum konusuna odaklanan kamuoyu çalışmaları, coğrafi yakınlıkları ve ortak dini hassasiyetlerine rağmen Türk toplumunun Suriyeliler'i kültürel olarak uzak ve farklı gördüklerini ortaya koymaktadır. Bu çalışma, Suriyeli mültecilerin ülke gündeminde oldukları dönemlere dönerek, o dönemin haber fotoğraflarında nasıl temsil edildiklerini, fotoğraflarda nasıl bir "Suriyeli mülteci" kimliği inşa edildiğini ve bu temsillerin Türkler ve Suriyeliler arasında kültürel farklılık ve uzaklık algısını nasıl beslemiş olabileceklerini sorgulamaktadır. Suriyeli nüfusun Türkiye'de en fazla artış gösterdiği 2014 ve 2015 yıllarında beş günlük gazetede yayınlanan Suriyeli mülteci fotoğrafları içerik analizi yöntemi ile incelenmiş, fotoğraflarda Suriyeliler'e dair hangi anlamların üretildiği belirlenmiş, biz-onlar ayrımının nasıl ve hangi temsil pratikleri ile inşa edildiği gözlemlenmiş ve bu temsillerin toplumsal kabule yönelik olası etkileri tartışılmıştır. Sonuç olarak, gazete temsillerinde Suriyeli mültecilere karşı önyargılı bir temsil biçiminin açık bir şekilde kullanılmadığı, ancak bazı temsil pratikleri ile daha örtülü şekillerde Suriyeliler'in toplumdan (bizden) farklı, uzak ve yabancı bir grup olarak inşa edildiği savunulmaktadır. Bu temsil biçimi, üç buçuk milyonun üzerinde Suriyeli nüfusa sahip Türkiye'de, Suriyeliler'e yönelik toplumsal kabulün oluşumuna olumsuz etki edecek niteliktedir. Toplum içerisinde barışın hâkim olabilmesi için medya temsillerinde, Suriyeli mültecilerin "görünmez" k1lınan ancak "bize" benzer "sıradan" ve olumlu özelliklerinin görünür kılınması önerilmektedir.
\end{abstract}

Anahtar Kelimeler: Suriyeliler, mülteciler, temsil, biz-onlar ayrımı, kültürel farklılık

Makale Türü: Araştırma

\begin{abstract}
Public opinion studies, which focus on the topics of social acceptance and cohesion between Turkish society and Syrian refugees, reveal that despite geographical and religious proximities Turkish society perceives Syrians as culturally different and distant. This study looks back at the years when Syrian refugees were on the public agenda and explores the representation and the construction of "Syrian refugee" identity in the news photographs of that period and considers how these representations might have fed the perception of cultural difference between Turks and Syrians. Through a content analysis method, the research studied the Syrian refugee photographs published in five newspapers in 2014 and 2015, investigated the meanings produced in the photographs, explored the use of representational practices in constructing us-them difference, and considered their implications for social acceptance. Consequently, it is discussed that the newspapers do not use an explicitly prejudiced representational practice towards Syrian refugees; however, in more subtle ways and through the use of certain representational practices Syrians are constructed as a social group different and distant from society (us). This representation practice prevents the production of social acceptance towards Syrians in Turkey. It is suggested that for social peace, representations should aim to portray those "ordinary" and positive
\end{abstract}

\footnotetext{
* Bu çalışmada, TÜBİTAK destekli 115K268 numaralı araştırma projesi kapsamında toplanan verilerin bir kısmı kullanılmıştır.

${ }^{1}$ Işık Üniversitesi, Fen Edebiyat Fakültesi, muzeyyen.pandir@isikun.edu.tr.
} 
characteristics of Syrians which show their similarities with "us" but which are made "invisible" in representations.

Keywords: Syrians, refugees, representation, us-them difference, cultural difference

Paper Type: Research

\section{Giriş}

2020 yılı sonu itibariyle Türkiye, üç buçuk milyonun üzerinde Suriye vatandaşına geçici koruma sağlamaktadır. Bu denli büyük bir sığınmacı/mülteci/göçmen² grubu ile halk arasında sosyal uyumun ve birlikte yaşama kültürünün kurulabilmesi, ülke için öncelikli konular arasında yer almaktadır. Sosyal uyum ve barış için elzem olanlardan biri, doğru devlet politikalarının geliştirilmesi ve uygulanması olduğu kadar, Suriyeli mültecilere yönelik kamuoyu algısının da barışa ve uyuma katk1 sağlayacak şekilde oluşturulması ve yönlendirilmesidir. Oysa bugün Türkiye'de bulunan Suriyeliler'e ve diğer mültecilere, Türk toplumu ile ilişkilerini zorlaştıran şeylerin neler olduğu sorulduğunda, ilk sırada toplumdaki mülteci algısını işaret etmektedirler (Özerim vd., 2020, s. 39).

Suriyeliler'e yönelik kamuoyu algısını ölçen çalışmalar, Suriyeliler'in Türkiye'ye sığındıkları ilk yıllarda, özellikle 2011-2015 yılları arasında, savaştan kaçan mağdur insanlar olarak görüldüklerini, bu yüzden de kamuoyunda onlara yönelik olumlu bir algının hakim olduğunu belirtmektedir (Erdoğan, 2015). Ancak Suriye'de savaşın uzaması, Türkiye'de Suriyeli nüfusunun artması ve Suriyeliler'in Türkiye'de kalıcı olacakları düşüncesinin halk arasında artması ile bu algının yıllar içinde olumsuza doğru değiştiği de belirtilmektedir (Erdoğan, 2018; Erdoğan, 2019; Nielsen, 2016, Saraçoğlu ve Bélanger, 2019). Murat Erdoğan tarafından 2017 ve 2019 yıllarında, 26 ilde, 2.089 ve 2.271 Türkiye Cumhuriyeti vatandaşının katılımıyla yürütülen iki farklı Suriyeliler Barometresi çalışmasına göre, Türkiye'de bulunan Suriyeliler ağırlıklı olarak olumsuz ve önyargılı şekillerde, "tehlikeli insanlar" ve "yük olan insanlar" olarak tanımlanmaktadır (Erdoğan, 2020, s. 55). Ayrıca anketlere katılanlar, Suriyeliler'i "kültürel açıdan farklı" olarak tanımlamakta ve bu cevap 2017'de de, 2019'da da \%80 gibi yüksek oranlarda ifade edilmektedir (2020, s. 61). Sonuç olarak Erdoğan, y1llar ilerledikçe kamuoyunda Suriyeliler'e yönelik olumsuz düşüncelerin arttığını belirtmektedir (2020, s. 55, 57).

Alg1 oluşumunda önemli toplumsal kurumlardan biri medyadır. Hatta Zygmunt Bauman'a göre gazeteler, televizyonlar ve sosyal medya, "kamusal kaygı ve korkuların odak ve çıkış noktaları" arasındadır (Bauman, 2016, s. 9). Öyleyse Türk basını, Suriyeliler'e yönelik algının olumsuz olmasında ne gibi bir rol oynamış olabilir? Bu sorudan hareketle bu çalışma, 2014 ve 2015 yıllarına geri dönerek, Suriyeliler'in en çok gündemde olduğu dönemde gazetelerin Suriyeliler'i nasıl temsil ettiklerini sorgulamaktadır. Bu iki yıl, Göç İdaresi Genel Müdürlüğü (2020) rakamlarına göre, Suriye'den Türkiye'ye göçün en yoğun yaşandığ dönemdir. Özellikle bu yoğun dönemde, medyada "mülteci krizi" diye adlandırılan olayın nasıl haberleştirildiği ve temsil edildiği, Suriyelilere yönelik algının bugünkü zemininin nasıl oluşturulduğunu incelemek ve anlamak için önemlidir.

Uluslararası ve ulusal akademik çalışmaların bulguları, genel olarak medyanın mültecilere yönelik tavırlarının olumlu ve olumsuz olmak üzere karışık olduğunu sergilemektedir (Mannik, 2012; Pandır vd., 2015; İGAM Raporu, 2019). Medyanın olumlu temsilleri, yakın durdukları siyasi gruplara ya da olumlu "biz" temsili gibi motivasyonlara dayanarak bu kırılgan grubun insani yardıma muhtaçlığını öne çıkarırken, olumsuz temsiller de

\footnotetext{
2 Ülkelerindeki savaştan kaçarak Türkiye'ye sığınan Suriyeliler, 13 Ekim 2014 tarihinde Bakanlar Kurulu'nca yürürlüğe koyulan Geçici Koruma Yönetmeliği uyarınca resmi olarak geçici koruma statüsü kapsamında tanınmaktalar. Medyada ve günlük dilde ise bu konumdaki Suriyeliler için sığınmacı, mülteci ve göçmen kelimeleri sıklıkla değişimli olarak kullanılmaktadır. Bu çalışma boyunca savaş nedeniyle Türkiye'de bulunan Suriyeliler için genel olarak Suriyeliler ve mülteci kelimeleri kullanılacaktır.
} 
yine siyasi nedenlerle önyargılı ve bazen 1rkçı söylemler içerebilmektedir. Irkçı söylemler genelde ev sahibi toplum ve mülteci gruplar arasında kültürel farkl1lık ve biz-onlar ayrımını kurgularken, "onlar"1 "biz"e ve kültürümüze karşı bir tehdit olarak konumlandırmakta ve iki grubun beraber yaşayamayacağı fikrini yaymayı amaçlamaktadır.

Suriyeli mülteci temsillerini incelerken bu çalışmanın ana sorusu, Suriyeliler'e yönelik kültürel farklılık ve kültürel uzaklık algısının temsil üzerinden nasıl inşa edildiği ile alakalıdır. Özellikle Suriyeli mülteci fotoğraflarına yoğunlaşarak, görsel temsil üzerinden nasıl bir Suriyeli imgesi ve algısı inşa edildiği, bu imge etrafinda ne gibi anlamlar üretildiği, ve bu imgenin beraber yaşama kültürüne olası etkileri tartışılmaktadır. Bu doğrultuda çalışma, 2014 ve 2015 yıllarında en yüksek tiraja sahip beş ulusal gazetede (Hürriyet, Posta, Sabah, Sözcü ve Zaman ${ }^{3}$ ) yayınlanmış Suriyeli mülteci fotoğraflarını içerik analizi yöntemi ile incelemektedir.

Aşağıda ilk olarak medyada mülteci/sığınmacı temsiline dair uluslararası ve ulusal çalışmaların ortaya koyduğu bilgiler derlenmektedir. Ardından sırasıyla çalışmanın yöntemi tanıtılmakta, gazetelerin Suriyeli mülteci fotoğraflarının içeriklerine dair bulgular paylaşılmakta ve son olarak fotoğrafların ne tür bir Suriyeli mülteci algısı inşa ettiği, bu algının kültürel farklılık ve biz-onlar ayrımı inşasına nasıl hizmet ettiği ve toplumsal kabule yönelik olası etkileri tartışılmaktadır.

\section{Medyada Sığınmacılar, Mülteciler ve Göçmenler}

Mülteci, sığınmacı ve göçmen gruplarının medyada temsilini ve haberleştirilme biçimlerini inceleyen çalışmalar, bu grupların "yabancı" statüsünde görülerek daha çok olumsuz şekillerde temsil edildiklerini aktarmaktadır. Azınlıkları ve göçmenleri konu alan klasikleşmiş çalışmasında Teun A. van Dijk (1991), İngiliz ve Hollanda gazetelerinde göçmenlerin ve etnik azınlıkların nasıl temsil edildiğini incelemekte, bu grupların haber metinlerinde, köşe yazılarında ve editoryallerde ağırlıklı olarak olumsuz bir çerçevede haberleştirildiğini, özellikle de "problem" ya da "tehdit" olarak tanımlandıklarını söylemektedir (1991, s. 245). Göçmen ve azınlıkların sıklıkla ilişkilendirildikleri konuların göç sorunları, suç, şiddet ve ayrımcılık gibi konular olduğunu belirtmekte; siyasi, toplumsal ve kültürel konular kapsamında daha az tartışıldıklarını söylemekte, tartışıldıklarında da yine haber kapsamının problem ve çatışma olduğuna değinmektedir. Bunun yanında azınlıkların günlük yaşamlarını ve toplum içindeki deneyimlerini aktaran haberlerin ise gazetelerde pek yer bulamadığını eklemektedir. Ayrıca van Dijk, gazetelerin göçmenlere ve azınlıklara, konu kendilerini alakadar eden ırkçı saldırılar ya da önyarg1 gibi konular olduğunda bile az söz hakkı verdiğini belirtmektedir (1991, s. 246).

van Dijk, temsillerin gazetelerin ideolojik duruşlarına göre nasıl değiştiğini değerlendirdiğinde ise, sağ görüşlü ya da muhafazakâr diye tanımlanabilecek gazetelerin (örneğin İngiliz The Times) ve de bulvar (tabloid) gazetelerinin göçmenler ve azınlıklarla ilgili olayları "biz" ve "onlar" arasında bir sorun olarak sunduğunu söylerken (1991, s. 246), daha liberal görüsse sahip ve ciddi diye nitelendirilen (örneğin İngiliz The Guardian, Fransız Le Monde, İspanyol El Pais) gazetelerin ise azınlıklarla ilgili konularda daha "ince" bir dil kullandığını, açıkça belirtilmiş önyargılı görüşlerin daha az yer aldığını, haberlerde arka plan bilgisinin daha geniş aktarıldığını ve azınlık gruplarının sözcülerine daha fazla söz hakkı verildiğini belirtmektedir. Ancak van Dijk'e göre bu, ciddi gazetelerin açıkça "irkçıllk karşıtı" bir bakış açısına sahip oldukları anlamına gelmemektedir (1991, s. 262). Çünkü ciddi gazeteler azınlıklarla ilgili konularda daha fazla sayıda haber yapıyor olsalar bile, azınlıkları yine çoğunlukla stereotipik konular etrafında temsil etmektedirler ve onları suç (uyuşturucu), şiddet, kültürel farklılıklar ve bir arada yaşamanın zorluklarıyla alakalı haberlerle anmaktadırlar (1991, s. 247-8). Dolayısıyla van Dijk'ın çalışmasından çıkarılacak bir sonuç, ciddi gazetelerdeki haber

\footnotetext{
${ }^{3}$ Zaman gazetesi 4 Mart 2016 tarihinde kayyum yönetimine geçmiş, 27 Temmuz 2016 tarihinde ise KHK kararı ile kapatılmıştır. Bugün yayın hayatına devam etmemesine rağmen 2014 ve 2015 yıllarında en çok satan gazeteler arasında olması ve mülteci söylemlerinin inşasında pay sahip olması nedeniyle analize dahil edilmiştir.
} 
dilinin de sorunlu olduğu, ancak bulvar gazeteleri ile karşılaştırıldıklarında göçmenlere ve azınlıklara karşı daha toleranslı göründükleridir.

Liisa Mannik (2012) de mültecilerle ilgili çalışmasında mülteci gruplarının temsillerinin mağduriyet ve tehdit temaları arasında iki farklı uçta değiştiğini söylemektedir. Mülteciler zayıf ve yardıma muhtaç mağdur kimseler olarak temsil edildikleri gibi, toplum için bir tehdit olarak da temsil edilmektedir. Bu temsil şekilleri çoğunlukla aynı biçimlerde tekrarlandığından, mültecinin etnik kimliği ne olursa olsun ortaya çıkan temsiller tarihsellikten uzak, birbirine benzeyen, stereotipik mülteci görüntüleri olmaktadır. Friedman ve Klein (2018) ise İngiltere’de mültecilere yönelik kamuoyu algısını değerlendirirken, İngiliz halkının mültecilere karşı önyargılı ve düşmanca tavırlarının ve onları güvenilmez olarak görmesinin en büyük sorumlusu olarak medyayı işaret etmektedir. Mülteci karşıtı medya kampanyalarının ülke içindeki mülteci/sı̆̆ınmacı sayılarını gerçekte olduğundan daha fazla gösterdiğini, devletin mültecilere sunduğu maddi, tıbbi ve barınma yardımlarını da abartarak sunduklarını aktarırlar. Böyle bir çerçeve içerisinde mülteciler, medya tarafından toplumun kaynaklarını tüketen kimseler olarak yansitılmaktadir.

Türkiye'de Suriyeli mülteciler ve medya odaklı çalışmalar ise Suriyelilerin Türkiye'de artan varlığıyla doğru orantılı olarak özellikle 2014 yılı itibariyle artış göstermektedir. İlk çalışmalar Suriyeliler'in sığınmacı, mülteci, göçmen ve kaçak gibi çeşitli terimler ile adlandırılmalarından doğan kafa karışıklıklarından bahsetmiştir (Kolukırık, 2009; Demir ve Erdal, 2010; Çakır, 2013). Daha sonraki çalışmalar Suriyeli mültecilerin ulusal basında, yerel basında ve sosyal medyada temsillerine değinmekte (Erdoğan, 2015; Yücebaş, 2015; Yaylacı ve Karakuş, 2016; Efe vd., 2018; Sunata ve Yıldız, 2018; İGAM Raporu, 2019; Pandır, 2019), bazıları temsillerdeki ayrımcı dile yoğunlaşmakta (Doğanay ve Keneş, 2016a), bazıları da konuyu hak temelli gazetecilik yaklaşımının yoksunluğu nedeniyle eleştirmektedir (Ataman, 2015; Doğanay ve Keneş, 2016b).

Genel olarak Türkiye'de Suriyelileri konu alan araştırmaların çalıştıkları medya, inceledikleri zaman dilimleri ve genişliği birbirinden farklılık gösterse de Suriyeli mülteci temsilleri ile ilgili pek çok ortak sonuca vardıkları söylenebilmektedir. Bu ortak noktaları özetleyecek olursak en önemlilerinden biri, haberlerde Suriyeli mültecilerin ağırlıkla yardıma muhtaç "mağdur" kimseler olarak ve de ülkeye ekonomik yük ve güvenlik sorununu getiren "tehdit" olarak kısıtll ve benzer biçimlerde temsil edildiğidir (Erdoğan, 2015; Pandır vd., 2015; Doğanay ve Keneş, 2016; Sunata ve Yıldız, 2018; Efe, 2019).

Mağduriyet temsili mülteciye yönelik kapsayıcı/olumlu bir bakış açısına sahip görünürken, tehdit temsilleri mülteciyi toplum için bir sorun olarak görmekte ve dışlayıcı/olumsuz bir rol oynamaktadır. Mültecinin hangi çerçevede nasıl temsil edileceğinin en önemli belirleyicisinin gazetelerin siyasi duruşları olduğu tartışılmaktadır (Erdoğan; 2015; Yaylacı ve Karakuş, 2015; Doğanay ve Keneş, 2016a; Efe, 2019). Buna göre hükümet ile daha yakın ilişkiler içinde olan gazeteler (örneğin Yeni Şafak, Sabah), mültecilere açılan sınır kapılarını yardıma muhtaç "kardeşlerimize" yönelik insani bir sorumluluk olarak göstermekte (Erdoğan; 2015, s. 151-2; Efe, 2019), mültecilerin Suriye'den kaçışlarını "katliamdan" kaçış olarak sunmakta, "huzuru ve barışı" Türkiye'de bulduklarını vurgulayarak hükümet politikalarına destek vermektedir (Yaylacı ve Karakuş; 2015). Hükümete ve politikalarına daha eleştirel bakan gazeteler ise (örneğin Sözcü ve Cumhuriyet), mültecilerin ülke içindeki varlığını "sorunsallaştırmakta", mülteciyi ekonomik yük, suç ve güvenlik sorunu gibi olumsuz konularla ilişkilendirerek onları bir "tehdit" olarak sunmakta ve bu tehdit algısını hükümet politikalarını eleştirmek için bir araç olarak kullanmaktadır (Doğanay ve Keneş, 2016; Paksoy ve Şentöregil, 2018).

Ancak yine de medyada mültecilere yönelik ayrımcı söylemlerin, mağduriyet temasına göre daha az sayıda tekrarlandığı eklenmekte (Erdoğan, 2015), ayrımcı dil kullanıldığında da bunun açıkça değil daha örtük olarak kullanıldığg belirtilmektedir (Pandır vd. 2015; İGAM 
Raporu, 2019). Bunun olası nedenlerinden biri, çalışmaların çoğunlukla en fazla satan ulusal gazeteleri incelemiş olmaları, bu gazetelerin çoğunun da hükümetle yakın ilişki içinde olan ve hükümetin mültecilere yönelik kapsayıcı bir politika yürütmesine destek vermiş gazeteler olmalarıdır. Hiç şüphesiz siyasi bir sebeple dahi olsa, medyanın kapsayıcı bir dil kullanması mültecilerin ülke içinde barınmasını kolaylaştırmakta, halk ve mülteciler arasında olası sorunların artmamasına yardımcı olmaktadır.

Ancak medyada ayrımcı dilin belirgin bir şekilde ortaya çıkmıyor oluşu, medyanın "onlar" ve "biz" ayrımı olmaksızın eşitliğe dayalı haber yaptığı anlamına gelmemektedir. Mülteciler ve halk arasındaki "farklılık" ya da "kültürel uzaklık" algısı haber dilinde çeşitli şekillerde üretilmekte ve ima edilmektedir. Bunun en yaygın biçimi, mültecilerin mağduriyet ve suç temalarına sıkıştırılmış bir biçimde temsil edilmesi, onları "herkes gibi" sıradan insanlar olarak temsil eden günlük yaşamlarına ve başarı öykülerine az yer verilmesidir (IGAM Raporu, 2019, s. 15; Pandır, 2019). Bu tarz temsillerin azlı̆̆ı, kamuoyunda "onlar" ve "biz" arasındaki benzerliklerin öne çıkmasını engelleyerek farklılıkların altını çizmekte, bu da toplumsal kabul ve bir arada yaşama düşüncesine olumsuz katkı yapmaktadır.

Son olarak, haberlerde mültecilerin nasıl bir bakış açısı ile temsil edildiği konusuna gelince, yardıma muhtaç mültecilerle ilgili haberlerin çokluğu, mültecilerin insani bakış açısı ile haberleştirildiğini göstermektedir (Sunata ve Yıldız, 2018). Haberlerde insani bakış açısının hakim olması başta olumlu gibi gözükse de, bu aynı zamanda, mültecilere yapılan yardımların sahip oldukları sosyal ve siyasi haklar üzerinden değil, ev sahibi ülkenin misafirperverliği ve hoşgörüsü üzerinden değerlendirildiği anlamına gelmektedir. Mülteci haklarının görünmez kılınmaması için önemli olan, siyasi haklara sahip olan mültecilerin hak temelli bir bakış açısından haberleştirilmesidir. Hak temelli bakış açısını içermeyen mülteci haberleri, mültecilerin uğradığı hak ihlalleri hakkında okuyucuya bilgi vermemekte, koşullarının iyileştirilmesi için yaptıkları hak talepleri hakkında sessiz kalmakta (Doğanay ve Keneş, 2016b; İGAM Raporu, 2019, s. 18) ve mültecilerin temel hakları için faaliyet gösteren sivil toplum kuruluşlarına sınırlı yer vermektedir (Ataman, 2015). Hak temelli bakış açısının yoksunluğu ve insani bakış açısının hakimiyeti, toplumu mültecilerin koruyucusu olarak konumlandırırken iki grup arasında hiyerarşik bir ilişki kurmakta, mültecileri güçsüz bir pozisyonda konumlandırmaktadır.

$\mathrm{Bu}$ bölümü bitirmeden önce eklemek gerekir ki, yukarıda bahsedilen mülteci temsillerini inceleyen araştırmalar ağırlıklı olarak haber metinlerinde kullanılan dil üzerine yoğunlaşmaktadır. Görsel temsili, özellikle de haber fotoğraflarını inceleyen çalışmalar azınlıktadır. Oysa ki, haber dili kadar mültecinin nasıl görüntülendiğini ve mülteci figürünün nasıl inşa edildiğini tartışmak da önemlidir çünkü fotoğraf, temsil edilen konuya dair dikkat çeken bilgiyi ilk aktaran iletişim aracıdır. Haber başlığı, haber fotoğrafı ve fotoğraf altı yazısı çoğunlukla okuyucunun göz attığı ilk noktalardır ve okuyucu bilgiyi bazen sadece bu öğelerden almakla yetinir. Dolayısıyla fotoğraflar, Suriyeli mültecilerle ilgili ilk izlenimin oluştuğu nokta olmalarından dolayı, algı oluşumunda önemli rol oynamaktadırlar. $\mathrm{Bu}$ hassasiyetlerden hareketle bu çalışmanın amaçlarından biri, Türkiye'de mülteciler ve medya alanındaki çalışmalara görsel temsili çalışarak katkıda bulunmaktır. Çalışmanın ikinci amacı ise haber fotoğraflarında Suriyeli mültecilere yönelik nasıl bir algı oluşturulduğunu tartışmak, özellikle de görsel temsil üzerinden biz ve onlar ayrımının ve kültürel farklılık algısının nasıl inşa edildiğini sergilemek ve bu bulguları, toplumsal kabule etkileri kapsamında tartışmaya açmaktır.

\section{Yöntem}

Bu çalışma kapsamında 1 Ocak 2014 ve 31 Aralık 2015 tarihleri arasında, en yüksek tiraja sahip beş ulusal gazetede yayınlanmış Suriyeli mültecilere ait haber fotoğrafları incelenmiştir. Suriyeli mülteci fotoğraflarının incelenmesinde nicel içerik analizi yöntemi kullanılmıştır. Fotoğrafın yanı sıra, fotoğrafa eşlik eden başlık ve fotoğraf altı yazısı da görselin anlamına katkıda bulundukları ve okuyucuyu yönlendirdikleri için fotoğrafın bir parçası olarak 
kabul edilmiş ve incelemeye dahil edilmişlerdir. Araştırma soruları şunlardır: 1) Fotoğrafta Suriyeli mülteciler nasıl adlandırılıyor/tanımlanıyor? 2) Hangi konu/olay/anlam etrafinda temsil ediliyorlar ve kimler görünür kılınıyor? 3) Fotoğraflar, Türkler ve Suriyeliler arasında "biz" ve "onlar" ayrımını nasıl inşa ediyor? 4) Bu temsil pratiklerinin Türkler ve Suriyeliler arasındaki ilişkiye olası etkileri neler olabilir?

Gazete tirajları ile ilgili veriler medyatava.com ve gazetetirajlari.com internet sitelerinden alınmıştır. Tiraj rakamlarına göre 2014 ve 2015 yılları içinde en fazla satış rakamına sahip ilk beş gazete sıralaması Hürriyet, Posta, Sabah, Sözcü ve Zaman gazeteleri arasında değişmektedir. Örnekleme bu beş gazete dahil edilmiştir. Gazetelerin tirajlarının esas alınmasının nedeni, daha çok kişiye ulaşan gazetelerin kamuoyu algısını yönlendirmede daha fazla potansiyele sahip olacakları düşüncesidir.

2014 ve 2015 yıllarının incelenme nedenleri, bu iki yılın 2011 ve 2020 yılları arasında Suriye'den Türkiye'ye göçün en yoğun yaşandığı yıllar olması ve bu dönemde Suriyeliler'in kamuoyunda çok daha fazla tartışmaya konu olmasıdır. 2013 yılında Türkiye'deki kayıtlı Suriyeli sayısı 224.655 iken, savaşın kızışması ile bu rakam 2014 ve 2015 yıllarında sırasıyla 1.294.631 ve 984.263 artışla 2.503.549'a ulaşmıştır (Göç İdaresi Genel Müdürlüğü, 2020). Daha sonraki yıllarda Suriyeliler'in göçü devam etse de artış önemli şekilde azalmış ve Suriyeliler özellikle 2016 yılı itibariyle medya gündeminde daha az yer almaya başlamıştır. Medyada sık yer aldıkları dönemde nasıl temsil edildiklerini incelemek, bugün geldiğimiz noktada Murat Erdoğan'ın (2020) ortaya koyduğu gibi onlara dair kamuoyu algısının nasıl olumsuz bir hale dönüştüğünü sorgulamak ve anlamak için önemlidir.

Örneklemi oluşturan haber fotoğraflarının taranması, özel bir medya takip şirketi tarafından yapılmıştır. Suriyeliler, sığınmacılar, mülteciler anahtar kelimeleri ile yapılan tarama sonucunda elde edilen haberler gözden geçirilmiş, sadece Suriyeli mülteciler ve sığınmacılar ile ilgili haber fotoğrafları örnekleme dahil edilip analiz edilmiştir. İncelenen beş gazetede 2014 yılında 440, 2015 yılında 882 Suriyeli mülteci fotoğrafı yayınlanmıştır. Buna göre bu çalışma kapsamında incelenen haber fotoğraflarının toplam sayısı 1322' dir.

Fotoğrafların analizinde, Philip Bell'in (2001) içerik analizi için geliştirdiği yöntem esas alınmıştır. Buna göre, analiz için Excel programı yardımıyla bir kodlama yönergesi hazırlanmış, bu yönerge üzerine fotoğrafların içeriğine dair incelenmek istenilen "kategoriler" eklenmiş ve analiz sırasında bu kategoriler "içerikleri/değerleri" kodlama yönergesine işlenerek kodlama süreci ve içerik analizi tamamlanmıştır. Bu süreç sonunda fotoğrafların Suriyeli mültecileri nasıl temsil ettiklerine dair istatistiksel veriler elde edilmiştir.

İçerik analizi için belirlenen kategoriler, araştırma sorularının amaçlarına göre belirlenmiştir. $\mathrm{Bu}$ çalışma kapsamında, aşağıdaki Bulgular bölümünde şu altı kategori incelemeye dahil edilmiştir: "adlandırma", "konu/anlam", fotoğrafta "öne çıkarılanlar" (aktörler), ve biz/onlar ayrımının inşasını yorumlamak için fotoğraftaki "kişi sayısı", "çekim açısı" ve "lokasyon". Bu kategorilerin çoğu, fotoğrafın kolayca gözlemlenebilir objektif özelliklerini ortaya koymaktadır. Fotoğrafta işlenen konunun ne olduğu sorusu ise daha çok kodlayıcının yorumuna dayalı bir kriterdir. Kodlayıcının değerlendirmelerinin tutarlılığını ve güvenirliğini sağlamak için bazı önlemler alınmıştır.

Kodlamaların tutarlılı̆ğı sağlayabilmek için tüm fotoğrafların kodlaması tek bir kişi tarafından yapılmış, proje ekibi ile düzenli aralıklarla yapılan toplantılarda kararsız kalınan kodlamalar beraberce tartışılmış, tüm kodlamaların bitiminde ise kodlamalar proje ekibinden ikinci bir kişi tarafından kontrol edilmiş, birinci ve ikinci kodlayıcılar arasında fikir ayrılığının görüldüğü durumlarda kodlayıcıların görseli beraber değerlendirmesi ile nihai karar verilmiştir.

İçerik analizi sonucunda elde edilen veriler, gazetelerin Suriyeli mültecileri hangi konularla ilişkilendirerek temsil ettiği, hangi temsil pratiklerinin kullanıldığı ve bu pratiklerin mülteciye dair nasıl bir anlam ve algı oluşumuna hizmet ettiği ve en nihayetinde bu anlamların 
biz-onlar algısını nasıl yönlendirdiği ve Türk vatandaşları ile Suriyeliler arasındaki ilişkiyi nasıl etkileyebileceği yönündeki soruların cevaplanmasına yardımcı olmaktadır.

\section{Bulgular: Haber Fotoğraflarında Suriyeli Mülteci Temsili, 2014 ve 2015}

\subsection{Suriyeli mülteciler fotoğraflarda nasıl adlandırılıyor?}

Suriyeliler'in savaştan kaçarak Türkiye'ye sığındıkları ilk yıllarda nasıl adlandırılmaları gerektiği konusu siyasi aktörler, medya ve akademisyenler için genel bir soru olmuştur. Türk yasalarında mülteci kelimesinin sadece Avrupa ülkelerinden gelen sığınmacıları kapsıyor olması nedeniyle Türk hükümeti, özellikle ilk yıllarda, Suriyeliler'in toplum içindeki kabullerini de kolaylaştırmak amacıyla onlar için siyasal statülerini belirten kimlikler değil de "komşularımız" ve "misafirlerimiz" gibi ortak kültürel değerleri vurgulayan tanımlamalar kullanmayı tercih etmiştir (Dağtaş, 2017). Bu durum, Suriyelilerin ne şekilde adlandırılması gerektiği konusunda bir belirsizliğe sebep olmuş ve çeşitli mecralarda Suriyeliler için sığınmacı, mülteci ve göçmen adlandırmaları dönüşümlü olarak kullanılmıştır. $\mathrm{Bu}$ nedenle gazetelerde Suriyelilerin hangi adlarla ya da kimliklerle tanımlandıkları gazetelerin bu gruba bakış açısını anlamak için önemli hale gelmiştir.

$\mathrm{Bu}$ tanımlamalar doğal olarak çoğunlukla haber metni içinde yer almaktadır. Bu nedenle fotoğraf açıklamalarına ya da haber başlıklarına baktığımızda fotoğrafların neredeyse yüzde 30'unda $(389, \% 29,42)$ Suriyeliler için herhangi bir adlandırma ya da tanımlamanın kullanılmadığı görülmektedir. En çok etnik/kültürel kimlikleri üzerinden, sadece "Suriyeliler" $(480, \% 36,3)$ olarak adlandırılmaktadırlar. Mülteci $(164, \% 12,4)$, sığınmac1 $(94, \% 7,11)$ ve göçmen $(58, \% 4,38)$ kelimeleri bu sırayla ve daha az sıklıkta karşımıza çıkmaktadır. Daha az sayıda fotoğrafta ise $(40, \% 3,02)$ Suriyeliler kaçak olarak tanımlanmıştır (Tablo 1).

Tablo 1. Fotoğraf altı yazılarda ve başlıklarda Suriyeli mültecilerin adlandırılması

\begin{tabular}{|lrr|}
\hline Adlandırma/tanımlama & Siklık & Oran \% \\
\hline Suriyeli & 480 & 36,30 \\
\hline N/A & 389 & 29,42 \\
\hline Mülteci & 164 & 12,40 \\
\hline Sı̆̆ınmacı & 94 & 7,11 \\
\hline Göçmen & 58 & 4,38 \\
\hline Çocuk & 57 & 4,31 \\
\hline Kaçak & 40 & 3,02 \\
\hline Kendi isimleri & 38 & 2,87 \\
\hline Kardeş & 2 & 0,15 \\
\hline Toplam & 1322 & 100 \\
\hline
\end{tabular}

Hangi siyasi statünün kullanılması gerektiğine dair kafa karışıklığı verilerde görülmektedir ancak genele bakıldığında siyasi statü ifade eden adlandırmalar (mülteci, sığınmacı, göçmen) toplamda $316(\% 23,9)$ fotoğrafta kullanılmıştır. Suriyeliler adlandırmasının, siyasi statüleri ve hakları ifade eden bu adlardan daha sık kullanılmasında bazı sorunların olduğunu söyleyebiliriz. Öncelikle, siyasi bir kimliğin/tanımın kullanılmaması ile Türkiye’ye sığınan bu insanların Türkiye'de bulunma nedenleri unutulmakta (İGAM Raporu, 2019, s. 40) ve statülerinden dolayı sahip oldukları haklar görünmez kılınmaktadır. Önceki bölümde bahsi 
geçen çalışmalar da Suriyeli mülteci konulu haberlerde Suriyeliler'in haklarına değinilmediği bilgisini desteklemektedir (Doğanay ve Keneş, 2016b; İGAM Raporu, 2019, s. 18). Bu durum özellikle tartışmalara konu olduklarında hangi haklar çerçevesinde ve hangi bakış açısından değerlendirilmeleri gerektiğini belirsizleştirmekte ve hak temelli bir gazetecilik anlayışı içinde tartışılmalarını engellemektedir. İkinci olarak, "Suriyeliler" genel başlı̆̆1, yanlış bir şekilde, Türkiye'de bulunan Suriyeli mülteci grubunu kendi içinde homojen bir grup olarak temsil etmektedir. Oysa ki bu büyük grup, çalışan/çalışmayan, işyeri sahibi olan/olmayan, okuyan/okumayan, eğitimli/eğitimsiz, genç/yaşlı, kadın/erkek kısacası çok farklı ve çeşitli özelliklere ve ihtiyaçlara sahip kişilerden oluşmaktadır. Ancak Suriyeliler genel başlı̆gı, bu kişiler arasındaki farkları silmekte ve onları etnik kimlikleri üzerinden birbiriyle aynı özelliklere sahip bir grup olarak temsil etmektedir. Böylece Suriyeliler adı, Suriyeliler'i kendi içlerinde genelleştirirken, aynı zamanda Suriyeliler'i (onlar) ve Türkler'i (biz) birbirinden farklı etnik gruplar olarak konumlandırarak iki grup arasındaki kültürel farklılıkları vurgulamaktadır. $\mathrm{Bu}$ haliyle adlandırma, mülteci grup ve ev sahibi grup arasında muhtemel bir sosyal uyumdan çok, uzaklığa ve ayrilığa hizmet etmektedir.

"Kaçak" kelimesi $(40, \% 3,02)$ ise az sıklıkta kullanılsa da göçmen kelimesine yakın bir oranda kullanılmaktadır ve kullanımıyla ortaya çıkan sorunları değerlendirmek önemlidir. Kaçak kelimesi, Suriyeliler'i yasadışılık ve suç ile ilişkilendirirken, onların ülkelerini terk etmek zorunda kalan ve kendilerine yeni bir yaşam arayan insanlar olduğu gerçeğinden ziyade, Türkiye'ye yasadışı yollardan giren "yasadışı" insanlar oldukları vurgusunu yapmaktadır. Oysa ki, kişileri kaçak ya da yasadışı olarak tanımlamak onların "insanlığını reddetmektir", göç ya da mültecilik gibi meseleleri de suç olarak göstermektedir. Bu nedenle, Kayıtsız Göçmenler için Uluslararası İşbirliği Platformu (The Platform for International Cooperation on Undocumented Migrants, PICUM), kaçak kelimesinin insanlar için kullanılamayacağı, gerekirse "kayıtsız" ya da "düzensiz" göçmen tanımlamalarının kullanılması gerektiği konusunda uyarıda bulunmaktadır (PICUM, 2020). Sonuç olarak, kaçak kelimesinin Suriyeliler için kullanımı yanlış olduğu gibi, kullanıldığında bu grubu suçluymuş gibi göstermekte, onları halk için bir tehdit olarak konumlandırmakta ve halk arasında Suriyeliler'e karşı düşmanca fikirleri ve tavirları beslemektedir.

\subsection{Suriyeli mülteciler fotoğraflarda hangi konularla/anlamlarla ilişkilendiriliyor?}

Suriyeli mültecilerin hangi durumlar içerisinde, hangi konularla ilişkilendirilerek temsil edildiği ve görünür kılındığı kamuoyunda onlar için oluşan algının şekillenmesinde önem taşımaktadır. Fotoğraflarda öne çıkan konular incelendiğinde görülüyor ki fotoğrafların çoğunda Suriyeli mülteciler, zorlu yaşam şartları içinde "yardıma muhtaç" ve "yoksul" $(434, \% 32,82)$ kimseler olarak temsil edilmektedirler. Mağduriyetleri yoksullukla sınırlı kalmamakta, başka biçimlerde de aktarılmaktadır. Örneğin mülteciyi ellerinde ve sırtlarında eşyalarıyla yaşadığ 1 yeri terk eden "yerinden edilmiş" kişiler $(332, \% 25,11)$ olarak, başka bir ülkeye göç ederken kazaya ya da şiddete maruz kalmış "mağdur/kurban" $(178, \% 13,46)$ olarak da görmekteyiz. Yoksulluk, yerinden edilmişlik ve kurban konularının işlendiği bu fotoğraflar, farklı mağduriyet biçimlerini temsil etmekteler ve mülteci görsellerinde öne çıkan konular arasında ilk üç sırada yer almaktalar. Bu konular beraber düşünüldüklerinde, mağduriyet toplamda 1322 fotoğrafin 944'ünde $(\% 71,40)$ öne çıkmaktadır, bu da Suriyeliler'in ağırlıklı olarak mağduriyet ile ilgili konular etrafinda temsil edildiğini göstermektedir (Tablo 2).

Mağduriyet, evlerini terk etmek, yeni bir ülkeye sığınmak ve yerleşmek zorunda kalan insanların bu süreçte yaşadıkları çeşitli deneyimlerin önemli bir parçası olduğu için, mülteci deneyimlerinin temsilinde çeşitli mağduriyet biçimlerinin öne çıkması ve mültecinin ağırlıklı olarak kurban rolünde temsil edilmesi şaşırtı değildir. Hatta ev sahibi toplum açısından düşünüldüğünde, mültecinin yardıma muhtaç mağdur insanlar olarak temsil edilmesi, bu denli büyük ve yabancı bir grubun ülkeye kabulü için gerekçe sunmakta ve ülkedeki varlıklarını meşrulaş̧ırmaktadır, dolayısıyla toplumsal kabule de destek vermektedir. Ancak, mültecinin ülkedeki varlığının mağduriyet üzerinden gerekçelendirilmesinin uzun vadede bazı sakıncaları 
olabilmektedir. "Mağdur" algısı mültecinin ülke içindeki varlığına bir süre için gerekçe sunuyor olsa da, bu alg1, savaş bittikten ya da mağduriyet ortadan kalktıktan sonra mültecinin kendi ülkesine geri dönmesi beklentisini de ortaya çıkarmakta (İGAM Raporu, 2019) ve aslında kalıcı bir toplumsal kabulü gerçekleştirememektedir. Daha önceki çalışmalar da, mağdur ya da kurban profili çizmeyen mültecilerin halk tarafından "gerçek mülteci" olarak görülmediğini (Mannik, 2012) ve bunun farkında olan mültecilerin kurumlardan yardım almaya devam edebilmek için mağdur rolünü bilinçli olarak gerçekleştirdiklerini belirtmektedir (Harrell-Bond, 2002). Dolayısıyla, Suriyeliler'in Türkiye'deki varlığının sığınma hakları üzerinden değil de ağırlıklı olarak mağdur figürü üzerinden meşrulaştırılması, Suriyeli mültecilerin güçlenmesi durumunda toplumsal kabulün tersine işleme potansiyelini doğurmaktadır ve Suriyeliler ile Türkler arasında kalıcı bir yakınlaşmanın ve kabulün ortaya çıkmasını güçleştirmektedir.

Tablo 2. Suriyeli mülteci fotoğraflarında öne çıkan konular ve anlamlar

\begin{tabular}{|lrr|}
\hline Konu/anlam & Siklık & Oran \% \\
\hline Yoksul, yardıma muhtaç & 434 & 32,82 \\
\hline Yerinden edilmiş & 332 & 25,11 \\
\hline Mağdur/kurban & 178 & 13,46 \\
\hline Tehdit & 132 & 9,98 \\
\hline Gündelik işler/sıradanlık & 78 & 5,90 \\
\hline N/A & 72 & 5,44 \\
\hline Dişlanmış & 50 & 3,70 \\
\hline Aktif & 26 & 1,96 \\
\hline Göçmen & 20 & 1,51 \\
\hline Toplam & 1322 & 100 \\
\hline
\end{tabular}

Mağduriyet temsilinin ardından, Suriyeli mülteci fotoğraflarında ikinci olarak "tehdit" konusu, mağduriyete oranla çok daha az sıklıkta ortaya çıksa da, yine de kayda değer şekilde yer almaktadır $(132, \% 9,98)$. Bu fotoğraflarda mülteciler büyük-küçük gruplar halinde ve "kayıtsız" bir şekilde Türkiye'ye girerken, yasadışı yollardan diğer ülkelere ulaşmaya çalışırken, veya kamp hayatında ya da şehir içinde şiddet olaylarına karışmış bir halde görülmektedir. Dolayısıyla Suriyeli mülteci suç ve şiddet olaylarıyla ilişkilendirilerek tehdit olarak temsil edilmektedir.

Tablo 2'de görüldüğü gibi, Suriyeli mültecilerin mağdur (944 fotoğraf) ve tehdit (132 fotoğraf) olarak gösterildiği fotoğraflar, incelenen beş gazetede yayınlanan 1322 fotoğrafın toplamda 1076'sını $(\% 81,39)$ oluşturmaktadır. Tehdit konusu mağduriyete göre daha az işleniyor olsa da, mağduriyet konusunun ardından gelen ikinci konu olması nedeniyle, Türk gazetelerinin Suriyeli mülteciye yüklediği anlamın tipik olarak mağduriyet ve tehdit konularına sıkışmış olduğunu göstermektedir. Bu durumun bir sonucu olarak, yine tabloda görüldüğü gibi, mülteciler dramatik olmayan, daha önemsiz görülebilecek ama daha olumlu nitelikte olaylar içinde pek sik temsil edilmemektedir.

Örneğin Suriyeli mültecinin her hangi bir "günlük, sıradan iş" ile meşgul görüldüğü fotoğraf sayıs1 $78(\% 5,90)$ iken, Türkiye'de iş kurmuş veya kendi geçimini başarılı bir şekilde sağlayan ve "göçmen" diye nitelendirilebilecek Suriyelilerin görüldüğü fotoğraf sayısı sadece 20 'dir (\%1,51). Ayrıca mülteciyi konuşurken, kendini ifade ederken, bir diğer deyişle edilgen 
değil de "aktif" rolde görüntüleyen fotoğraf sayısı da sadece 26 'dır $(\% 1,96)$. Burada bahsi geçen gündelik işler, göçmen ve aktif temaları, beraber değerlendirildiklerinde ancak \%9,37 temsil oranına ulaşmakta ve tehdit temasının oranına yaklaşmaktadır. Mülteci temsilinde pek az yer verilen bu konular, mülteciyi bizlere daha benzer "sıradan" özelliklerle temsil eden konulardır ve özellikle göçmen teması Suriyeliler’i kendine yetebilen ve topluma katkı sağlayabilen insanlar olarak temsil etmektedir. Bu nedenle bu üç konu, mültecinin ev sahibi toplum ile ortak noktalarını öne çıkaran, gruplar arasındaki farklılık hissini azaltan ve toplumsal kabule ve uyuma olumlu etki edebilecek tarzda fotoğraflardır. Bu tarz temsillerin sayılarının çoğalması toplumsal barış için önem arz etmektedir.

Sonuç olarak, mülteci fotoğraflarında öne çıkan konular beraber değerlendirildiğinde bu sonuçların kültürel farklılık inşasına etkisi hakkında şunlar söylenebilir: mültecinin kamuoyunda ağırlıklı olarak mağdurlaştırılması, zaman zaman tehdit olarak gösterilmesi ve mültecinin ev sahibi toplum ile ortak noktalarını gösteren temsillerin az olması, kamuoyunda mülteciyi halkın yardımına muhtaç ve "farklı" bir grup olarak inşa etmektedir. Türk toplumu ile ilişkisini mağduriyet ve muhtaçlık üzerinden kurgulamak mültecinin mağdur olduğu müddetçe ülke içinde barınacağı fikrini canlı tutmaktadır. Belki de bu nedenle gazeteler mülteci başarılarına yer vermeyi pek tercih etmemektedir.

\subsection{Suriyeli mülteci fotoğraflarında kimler, nasıl görünür kılınıyor?}

Suriyeli mülteci fotoğraflarında kimlerin yer aldığının incelenmesi, fotoğrafta gösterilen durumun kim üzerinden aktarıldığına, kimlerin görünür/görünmez kılındığına dair bilgi vermektedir. 1322 fotoğrafta hangi Suriyeli mültecinin öne çıkarıldığ incelendiğinde, mülteci çocukların daha fazla fotoğraflandığı görülmektedir. Çocukların yalnız başlarına $(265, \% 20,04)$, kadınlarla beraber $(150, \% 11,34)$ ve erkeklerle beraber $(112, \% 8,47)$ görüldüğü fotoğrafların toplam sayıs1 527'dir $(\% 39,86)$ (Tablo 3). Çocuk mültecilerin görüldüğü toplam 527 fotoğrafın yarısından fazlasından $(292, \% 55,40)$ yardım ve mağduriyet konusu işlenmektedir. Fotoğrafların genelinde en sik mağduriyet konusunun işlendiği düşünüldüğünde, en sık görünenlerin çocuklar olması şaşırtıcı olmamaktadır. Masumiyetlerinden ötürü çocukların, yerinden edilmişliğin neden olduğu zorlukları sergilemek için medya tarafından "ideal kurban" olarak seçilmeleri sık görülen bir temsil biçimidir (Pandır, 2019).

Tablo 3. Suriye'de mülteci fotoğraflarında öne çıkan aktörler

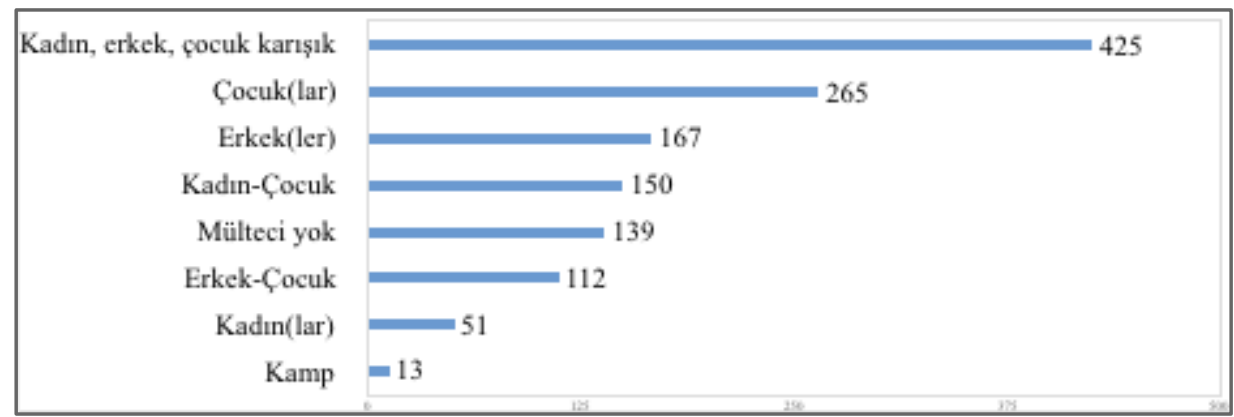

Suriyeli mülteci fotoğraflarında çocukların ardından karışık grup fotoğrafları öne çıkmakta, kadınların-erkeklerin-çocukların beraber fotoğraflandığı görülmektedir (425, \%32,14). Grup fotoğrafları, görüntüledikleri insanları "Suriyeliler" ya da "Suriyeli mülteciler" olarak genel bir kategori olarak temsil etmekte, bu şekilde mültecilerle ilgili konular ve sorunlar genelleştirilerek işlenmektedir. Genelleştirerek temsil etme biçimi, mülteci çocukların, kadınların ve erkeklerin ayrı ayrı yaşayabileceği daha özel sorunların temsil edilmemesi, görülmemesi, mültecilerin temsilde kurgulanan deneyimlere (mağdur, tehdit) indirgenmesi, kısacası insani özelliklerinin göz ardı edilmesi demektir. Bu şekilde Suriyeliler çeşitli özelliklere sahip farklı insanlar olarak değil birbirleriyle aynı özelliklere sahip homojen bir grupmuş gibi temsil edilmektedir. Önceki sayfalarda bahsedildiği gibi bu temsil biçimi, 
Suriyelileri ev sahibi grup içinde farklı ve ayrı bir grup olarak konumlandırmakta, birlikte yaşama fikrinin oluşumunu olumsuz etkilemektedir.

Çocukların ve grupların ardından en çok erkek mülteciler temsil edilmektedir (167, \%12,63). Sadece erkeklerin görüntülendiği fotoğraflar, erkek-çocuk fotoğraflarından da, kadın mülteci fotoğraflarından da fazladır. Bu, erkeklerle ilgili konuların daha sık görünür kılındığ anlamına gelmektedir, ancak erkek mülteciler için şöyle bir durum da söz konusudur: erkek mültecileri ana özne olarak gösteren 167 fotoğrafın 49'unda mağduriyet teması işleniyorken, 35 'inde suç ve şiddet konuları işlenmektedir. Her ne kadar tehdit teması genel olarak diğer temalardan daha az tekrarlanıyor olsa da, tehdit teşkil edenler erkek mülteciler olarak öne çıkmaktadır. Kadınlar içinse farklı bir durum söz konusudur. Fotoğraflarda kadın temsillerinin azlığ1 dikkat çekicidir; kadınların tek başına özne olduğu fotoğraf sayısı 51'dir (\%3,85). Çocuklarla birlikte görüldükleri fotoğraf sayısı ise üç kat fazla, 150'dir (\%11,34). Bu durum, mülteci kadına özel konuların temsillerde neredeyse işlenmediğini; mülteciliğin, kadın-erkek eşitsizliğinden kaynaklı mevcut yaşam zorluklarına ne gibi yeni zorluklar kattı̆̆ının fotoğraflarda görülmediğini göstermektedir. Kadın mülteci, stereotipik olarak anne rolüne indirgenmekte ve o rolde görünür kılınmaktadır.

Sonuç olarak, çalışmada kadın ve erkek mültecilerin temsillerine dair elde edilen bulgular, diğer çalışmaların (Amores vd., 2020) da öne sürdüğü, kadın mültecilerin medyada daha az görünür olduğu, görüntülendiklerinde daha çok edilgen/pasif rollerde temsil edildikleri; erkeklerin ise kadınlardan daha fazla görünür kılındığı ve daha negatif ama aktif rollerde tehdit ya da sorun olarak temsil edildikleri görüşlerini destekler niteliktedir. Dolayısıyla kadın mülteciler daha az görünür kılınarak, erkek mülteciler ise olumsuz temsillerle görünür kılınarak toplumdan uzaklaştırılmaktadırlar.

\subsection{Suriyeli mülteci fotoğraflarında "biz" ve "onlar" algısı nasıl inşa ediliyor?}

Kamuoyunda mülteci algısının oluşumunda ve yönlendirilmesinde, görsellerde tercih edilen temsil pratikleri de önem taşımaktadır. Kullanılan bazı temsil pratikleri, görselde temsil edilen ve görsele bakan arasında belli tarzda etkileşim kurulabilmesine destek verebilmektedir. $\mathrm{Bu}$ etkileşim, taraflar arasında bazen sosyal ya da kişisel yakınlık hissini, bazen de uzaklık hissini harekete geçirmektedir (Bell, 2001). Uzaklık hissinin harekete geçirildiği durumlar, görsel üzerinden "biz" ve "onlar" ayrımının inşasında etkili olmaktadır. Biz-onlar ayrımı inşasında kullanılan temsil pratikleri fotoğraftaki kişi sayısı, çekim açısı ve fotoğrafın bağlamı ile ilgili olabilmektedir ve bu çalışmada da bu özellikler incelenmiştir (Bell, 2001; Bleiker vd., 2013).

Fotoğraftaki "kişi sayısı", mültecinin kalabalık bir grup içinde mi yoksa tek başına bir birey olarak mı görüntülendiği ile alakalıdır. Fotoğrafta az kişinin görüntülenmesi, temsil edilen kişilerin, onları herkesten ayıran fiziksel ve kişisel özelliklerinin öne çıkarılabilmesi ve empati duygusunun oluşabilmesi açısından önem taşımaktadır (Bleiker vd., 2013). Bu durum, "mülteci" diye sınıflandırılıp "bizlerden" ayrıştırılan insanların aslında kendi aralarında aynı özelliklere sahip homojen bir grup olmadıklarını göstermekte, bir diğer deyişle mülteciyi kişiselleştirmektedir. Mültecinin kişiselleştirilmesi, onun herkes gibi sıradan insan olduğunun ve bir tehdit oluşturmadığının anlaşılabilmesi açısından önemlidir. Fotoğrafta mültecilerin kalabalık bir grup olarak temsil edilmeleri ise okuyucunun bu kişileri, aynı grubun parçası olmaktan dolayı birbirleriyle aynı özelliklere sahip, kişisel farklılıkları olmayan insanlar olarak algılamasını sağlamaktadır. Bu temsil pratiği ile temsil edilenler homojenleştirilmekte ya da genelleştirilmekte, ve hatta "kitle" ya da "insan yı̆̆ını" olarak temsil edilmektedirler (Bleiker vd., 2013). Ek olarak, aynı özelliklere sahip bir grup insan olarak sinıflandırılmaları, "bizden" farklı bir grup oldukları düşüncesini de beraberinde getirmekte, böylece fotoğraf üzerinden onlar ve biz ayrımı inşa edilmektedir.

2014 ve 2015 yıllarında 5 gazetede yayınlanan 1322 fotoğrafinın 139'unda (\%10.51) mülteci görülmemektedir. Bunlar mültecilerin bulunduğu çeşitli ortamları, kamp ya da 
barınakları görüntüleyen fotoğraflardır. 256 fotoğrafta (\%19,36) mülteciler tek başlarına, 254 fotoğrafta da $(\% 19,21)$ 2-3 kişilik küçük gruplar olarak görülmektedir; yani fotoğrafların toplamda yüzde 39'u mültecileri kişiselleştirme potansiyeline sahiptir. Fotoğrafların yarısında ise $(675, \% 51,05)$ mülteciler dört kişiden fazla gruplar halinde görülmektedir (Tablo 4). Dört ve dört kişiden fazlasının görüldüğü fotoğraflar kişisel özelliklerin netliğinin yitirilmeye başladığı fotoğraflar olduğu için mültecileri genelleştirmekte ve hatta kitle olarak temsil etmektedir (Bleiker vd., 2013).

Fotoğrafların yarısında genelleştirme temsil pratiğinin olmasına karşılık, yüzde 39'unda kişiselleştirme pratiğinin olması çok da kötü bir oran gibi görünmemektedir. Ancak mültecilerin kişiselleştirilmesi için fotoğraflarda kullanılan "çekim açısı" da önemlidir. Kişiselleştirme, temsil edilenin kişisel özelliklerinin net bir şekilde öne çıkarılması ile ilgili ise, bunun için mültecilerin yakın plandan fotoğraflanmaları gerekmektedir. Yakın plan çekim ile, temsil edileni diğer herkesten ayıran özgün özellikler yakından gösterildiği gibi, temsil edilenin yüz ifadeleri ve duygu durumu da gösterilebilmekte, bu da biz ve onlar arasında yakınlık hissinin ve empati duygusunun ortaya çıkmasına yardımcı olabilmektedir. Bu nedenle Philip Bell (2001), yakın plan çekimlerinin, temsil edilenle fotoğrafa bakan arasında kişisel bir ilişki kurabildiğini dahi söylemektedir. Uzak mesafeden çekilen fotoğraflar ise kişilere ait detayların kaybolmasına neden oldukları için kişiselliği ortadan kaldırmaktadır. Ayrıca uzak mesafe çekimleri kadraja daha fazla kişi sığdırabildiği için kalabalık grup fotoğraflarında özellikle tercih edilmekte ve temsil edilenleri birey olarak değil genel bir grup ya da kitleler olarak temsil etmektedir.

Tablo 4. Suriyeli mülteci fotoğraflarında kişi sayısı

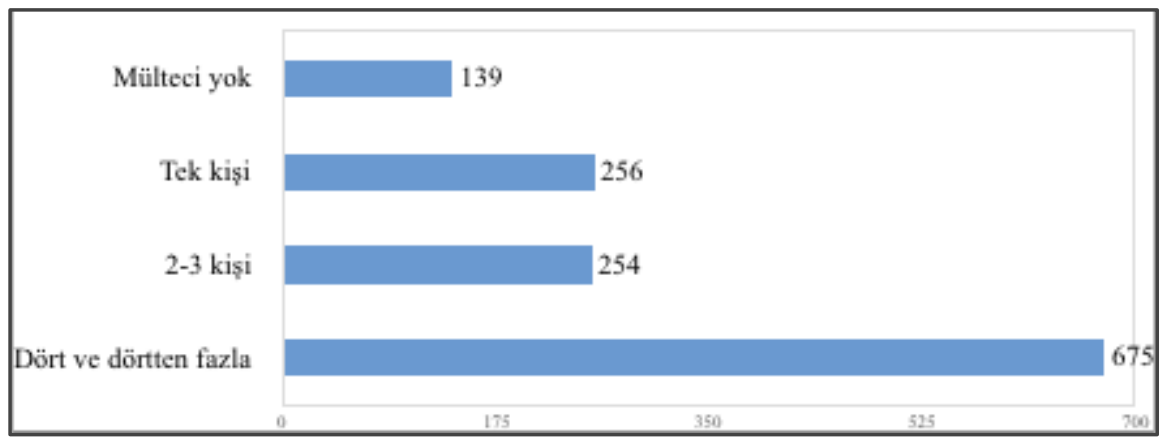

Fotoğraflarda çekim açısı yakın mesafe, uzak mesafe ve orta uzak mesafe olarak kodlanmıştır. Bell'den (2001) hareketle, fotoğrafta mültecinin yakın konumlandırıldığı, baş ve omuzlarının görüldüğü fotoğraflar yakın plan çekimleri olarak; mültecinin vücudunun neredeyse yarısının görüntülendiği fotoğraflar orta uzak mesafeli fotoğraflar olarak; mültecinin uzakta konumlandırıldığ 1 ve vücudunun tamamının görüntülendiği fotoğraflar ise uzak mesafe olarak kodlanmıştır.

Fotoğraflarda kullanılan kamera açısına bakıldığında fotoğrafların yarıdan fazlasının $(733, \% 55,44)$ Suriyeli mültecileri uzak mesafeden, 426'sının ise $(\% 32,22)$ orta uzak mesafeden görüntülediği görülmektedir. Uzak mesafe çekimlerinin toplam sayıları gösteriyor ki Suriyeli mülteciler ağıllıklı olarak kişiselleştirilmeden, genel bir kitle olarak, ve bizden ayrı ve uzak bir grup olarak temsil edilmekteler. Buna karşılık mültecinin yüz hatlarının ve yüz ifadesinin net bir şekilde ayırt edilebildiği, duygu durumlarının anlaşılabildiği yakın plan çekimlerin sayısı ise sadece 24 'dür $(\% 1,81)$. Bir diğer deyişle, mültecinin insani ve kişisel özelliklerini okuyucuya gösterebilecek fotoğrafların oranı, yok denecek kadar azdır (Tablo 5). 
Tablo 5. Suriyeli mülteci fotoğraflarında kişi sayısı

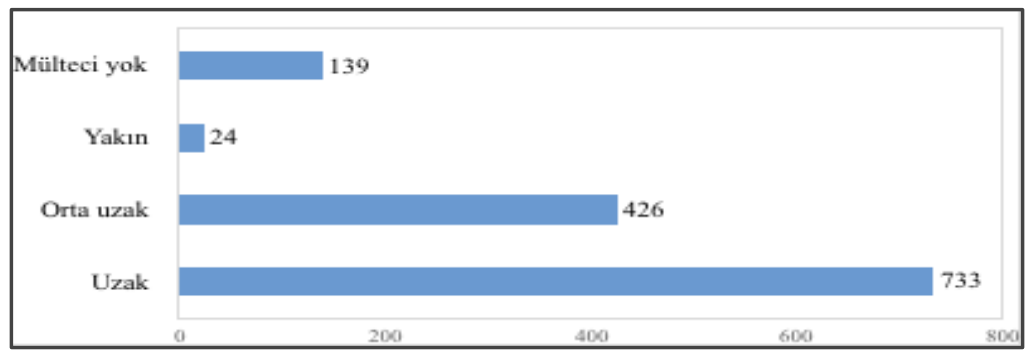

Son olarak, biz ve onlar arasındaki ilişkinin türünü belirlemede önemli bir diğer temsil şekli mültecilerin nerede, hangi bağlam içinde temsil edildiği ile ilgilidir. 1322 fotoğrafın dörtte birden fazlasının $(375, \% 28,36)$ nerede çekildiği net bir şekilde anlaşılamamıştır, yerin tespit edilebildiği fotoğrafların çoğunun ise sınırda çekildiği görülmüştür $(499, \% 37,74)$. Bunlar, mültecilerin kara ya da deniz sınırlarını geçerken görüldüğü ya da dikenli tellerin görüntülendiği fotoğraflardır. Mülteci fotoğraflarında konum olarak en fazla sınırların öne çıkıyor olması, konunun Suriye'den göç eden insanlar olması nedeniyle ve 2014 ve 2015 yıllarının göçün en yoğun yaşandığı yıllar olması nedeniyle şaşırtıcı değildir. Ancak, sınır temsillerinin bu insanlar için çağrıştırdığı anlamları düşünmek yine de önemlidir. Sınır, içeriyi dışarıdan ayıran yerdir. Sınırın bir tarafı bizi, diğer tarafı onları temsil eder. Mülteci temsilinde sınırların ön planda olması, mültecinin buraya ait olmama durumunu, dışarıdan ve yabancı olma durumunu hatırlatmaktadır. Aynı zamanda sınırları geçmek izne tabi olduğundan, izinsiz ya da yasadışı bir durumun ortaya çıkma ihtimalini de sürekli canlı tutmaktadırlar (Tablo 6). Bu nedenle fotoğraflarda tekrarlanan sınır imgesi, Suriyeliler'in buralı olmama, bizden olmama, ve hatta "gidici" olma durumunu vurgulamakta ve Türkler ve Suriyeliler arasındaki coğrafi ve kültürel farkl1lı fikrini canlı tutmaktadır.

Tablo 6. Suriyeli mültecilerin temsil edildikleri yer (bağlam)

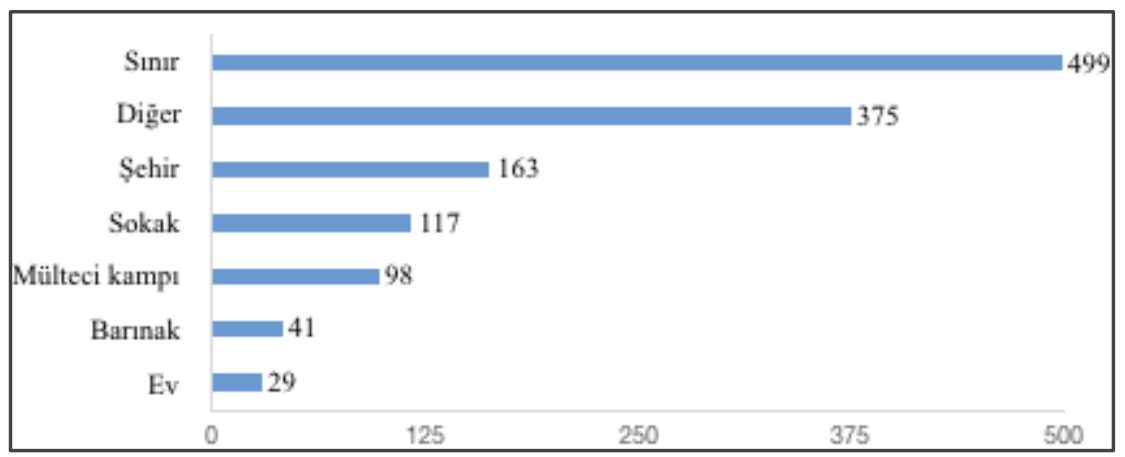

Benzer bir şekilde fotoğrafların 139'unda (\%10,51) mülteciler kamp ve barınaklarda görüntülenmektedir. $\mathrm{Bu}$ yerler de yine mültecileri şehir dışına iten ve şehirden uzaklaştıran yerler oldukları için, temsilde kullanıldıklarında onları bizim ortak mekânlarımızdan ayıran, sosyal hayatlarımızdan uzaklaştıran ve bizden farklılıklarını vurgulayan mekanlar olarak rol oynamaktadırlar. Bizlerle benzerliklerini gösteren ya da onları bizlerle aynı sosyal hayat içinde temsil edecek bir temsil özelliği, onları şehir içinde bizimle aynı yerde ya da ev ortamında görüntülemektir. Şehir içinde çekilen fotoğrafların sayısı $163(\% 12,32)$, ev ortamında çekilenlerin sayısı ise 29'dur $(\% 2,29)$.

Sonuç olarak, fotoğrafların sadece yüzde $15^{\prime}$ 'i, mültecileri ev sahibi toplum ile aynı sosyal mekânda (şehir ve ev) temsil etmektedir. Fotoğrafların neredeyse yarısında ise mülteciler sınır, kamp ve barınaklarda görüntülenmekte $(638, \% 48,26)$, böylece ev sahibi toplum ile farklı sosyal mekanlarda konumlandırılmaktadırlar. Ortak mekânların ayrı olması üzerinden Türklerin ve Suriyeliler'in sosyal ve kültürel hayatları da birbirinden ayrıştırılmakta ve uzaklaştırılmakta, böylece iki grup arasında farklılık ve uzaklık algısı inşa edilmektedir. 


\section{Tartışma, Sonuç ve Öneriler}

$\mathrm{Bu}$ çalışma, Suriyeli mültecilerin Türkiye'ye yoğun olarak giriş yaptığı ve Türk basınında yoğun olarak haberleştirildikleri önemli bir dönemde, 2014 ve 2015 yıllarında, gazete fotoğraflarında Suriyeliler'in nasıl temsil edildiğini incelemiş ve bu görseller üzerinden Suriyeliler'e yönelik nasıl bir kimliğin ve algının oluşturulduğunu tartışmıştır. Çalışmanın ardındaki önemli motivasyonlardan biri, bugün kamuoyu çalışmalarının ortaya koyduğu, Türk halkı arasında Suriyeliler'e yönelik artan olumsuz düşüncelerin ve Suriyeliler ile Türkler'in kültürel olarak birbirlerinden farklı olduğu algısının (Erdoğan, 2020), medya temsilleri üzerinden nasıl beslenmiş olabileceğini anlamaktır. Bu nedenle çalışma, fotoğrafların içerik analizi sonuçlarını sunarken, fotoğraflardaki temsil özelliklerinin Suriyeliler ve Türkler arasında kültürel yakınlık ya da uzaklık algısını nasıl kurduğunu sorgulamış ve bunların toplumsal uyuma ve kabule yönelik olası etkilerini değerlendirmiştir. İncelemede özellikle fotoğraflarda öne çıkan adlandırmalar, konular, aktörler ve diğer temsil pratikleri (fotoğraftaki kişi sayısı, çekim açısı ve yer) sorgulanmıştır.

Fotoğraflara eşlik eden açıklamalarda Suriyeli mülteciler genel bir adlandırmayla "Suriyeliler" olarak anılmaktadır. Mülteci, sığınmacı ya da koruma altındaki kişiler yerine Suriyeliler olarak genel bir şekilde adlandırılmak, Suriyeliler' in Türkiye'de sahip olduğu sosyal ve siyasi hakları görünmez kılmaktadır ve bu durum, varlıklarının hak temelli bir bakış açısıyla tartışılmasını destelememektedir. Böyle bir durumda Suriyeliler'e yapılan yardımlar mülteci olma durumundan sahip oldukları haklar olarak değil, ev sahibi grubun yüce gönüllüğü olarak yansıtılmaktadır. Oysaki, grubun sahip olduğu hakların medyada konuşulması ve bilinmesi, mülteciyi toplum içinde daha saygın konuma taşıyabilecek ve toplum içinde kabullerine yardımcı olabilecektir. İkinci olarak Suriyeliler adlandırması, Suriyelileri kendi içlerinde homojen bir grup olarak genellerken, Türk toplumu içinde de onları ayrı ve farklı bir etnik grup olarak konumlandırmakta, Türkler ve Suriyeliler arasında etnik/kültürel farklılık düşüncesini öne çıkarmaktadır. Bu durum biz-onlar ayrımını inşa ettiği gibi, iki grubun beraber uyum içerisinde yaşayabileceği fikrini de gölgelemektedir.

Fotoğraflarda öne çıkan konular incelendiğinde görülüyor ki Suriyeliler yoksulluk, yardıma muhtaçlık, yerinden edilmişlik ve kurban görüntüleri üzerinden ağırlıklı olarak "mağdur" insanlar olarak temsil edilmekteler. Suriyeliler'i "mağdur" olarak temsil etmek, Türkiye' de bulunma nedenlerini yardıma muhtaç oldukları gerekçesiyle meşrulaştırmakta ve bu durum ülke içinde kabul görmelerine bir süre için gerekçe sunmaktadır. Ancak bu durum, Suriye'deki savaş bittikten ya da mağduriyet ortadan kalktıktan sonra mültecinin ülkesine geri dönmesi beklentisini de beraberinde getirmekte, bu nedenle Suriyeliler ve Türkler arasında kalıcı bir sosyal kabulün oluşmasını güçleştirmektedir. Olması gereken, insanların bir yerde bulunma nedenlerinin sı ğınma hakları üzerinden meşrulaştırılması, mülteci politikalarının amacının da bu insanların güçlendirilip topluma katılmalarını sağlamak olduğu, ülkelerine geri göndermek olmadığ 1 düşüncesinin desteklenmesidir. Basında konunun bu çerçevede ele alınması, mültecinin toplum içindeki yerinin daha sağlıklı bir şekilde düşünülmesine yardımcı olacaktır. İkinci olarak, Suriyeli mültecinin yardıma muhtaç figürüne sıkıştırılarak temsil edilmesi, mültecilerin medyada sıradan günlük deneyimleri ve başarıları ile yer almasını engellemektedir. Bu temsil biçimi, mülteci ve ev sahibi toplum arasındaki yakınlaşmanın ortaya çıkmasını güçleştirmektedir. Oysaki mültecilerin günlük, sıradan deneyimlerinin ve hayatlarını yeniden kurmakta elde ettikleri başarılarının aktarılması, "bize" benzer ya da bizimle ortak ve takdir edilecek özelliklerinin görülmesini sağlayacak ve bir arada yaşama pratiğine olumlu etki sağlayacaktır.

Fotoğraflarda kimlerin öne çıkarıldığı incelendiğinde, Suriyeliler'in çoğunlukla gruplar halinde temsil edildiği görülmüştür. Grup temsilleri, insanları Suriyeliler ya da Suriyeli mülteciler olarak genelleştirmekte, kadın-erkek-çocuk-genç-yaşl1-eğitimli-eğitimsiz fark etmeksizin her Suriyeli'yi aynı özelliklere sahipmiş ve Suriyeliler kendi aralarında aynı, homojen bir grupmuş gibi hayal etmektedir. Bu temsil biçimi, Suriyeliler'in kendi aralarındaki 
kişisel farklılıkları yok etmekte, onlara birey olma hakkı tanımamakta, onları "mülteci" sınıfına sıkıştırmakta ve yaşadıkları çeşitli deneyimleri mülteci deneyimi olarak sınırlandırmaktadır. Böylelikle mültecilerin kişilik özellikleri, yaşamları ve deneyimleri, "biz" gibi insanlardan tamamen farklıymış gibi gösterilmekte, bu da iki grup arasında sosyal ve kültürel farklılıklar olduğu düşüncesini beslemektedir.

Fotoğraflarda Suriyeli mültecilerin nasıl konumlandırıldı̆̆ına bakıldığında yine görülmüsşür ki ağırlıkla uzaktan ve büyük gruplar halinde görüntülenmekteler. Bu tarz çekimler kişilerin yüzlerini ve duygu durumlarını çok net gösteremedikleri için insani özelliklerini görünmez kılmakta, temsil edilenlerle karşı empati duygusunun ortaya çıkmasına da engel olmaktadır. Ayrıca sıklıkla sınırlarda ve kamplarda görüntülenmeleri mültecilerin sosyal yaşamlarını bizden ayrıştırmakta, böylece bizden uzak ve bize yabancı bir sosyal grup olarak yansıtılmaktadırlar. Kısacası, fotoğraf çekimlerinde temsil edilen ile okuyucu arasında yakınlık ve empati kurulmasını sağlayacak çeşitli pratikler kullanılabilmesine rağmen (örneğin küçük gruplar halinde, yakın mesafeden, ortak mekanlarda görüntülemek gibi), bu pratiklerin Suriyeli mülteciler için kullanılmadığı görülmektedir.

Sonuç olarak bu çalışma, Türk gazetelerinde Suriyeli mültecilerin açıkça bir tehdit olarak temsil edilmediğini, onlara karşı önyargılı ve ayrımcı bir temsil şeklinin görünür bir şekilde kullanılmadığını, ancak temsillerin göze batmayacak başka yollarla biz ve onlar arasında ayrım, fark ve uzaklık hissini inşa ettiğini savunmaktadır. Kamuoyunda Suriyeli mültecilere yönelik algı bu tarz temsillerle beslendiğinden, bugün, akademik çalışmaların ortaya koyduğu, halk arasında Suriyeliler'in kültürel olarak farklı olduğu düşüncesi şaşırtıcı olmamaktadır. Ancak, bugün Türkiye'de sayıları üç buçuk milyonu aşan Suriyeli mültecilerin pek çoğunun ülkede kalıcı olduğu düşünülürse, toplum içinde barış ve uyum ortamının hâkim olabilmesi için, temsilde kullanılan dilin ve görselin, Suriyeli ve Türk grupların bir arada yaşayabileceği ve sağlıklı bir sosyal ilişki kurabilecekleri fikrine olumlu katkıda bulunması önemlidir. Bunun için, gazetelerin basmakalıp temsil biçimlerinden vazgeçip Suriyelilerin "görünmez" kılınan daha olumlu, sıradan ve insani özelliklerini görünür kılmaları önem taşımaktadır.

\section{Kaynakça}

Amores, J.J., Arcila-Calderón, C. ve González-de-Garay, B. (2020). The gendered representation of refugees using visual frames in the main western european media, Gender Issues, 37, 291-314.

Ataman H. (2015). Yazılı basında ayrımcı söylem: Suriyeli mülteciler. İ. Engindeniz ve H. Ataman (Ed), Medyada Nefret Söylemi ve Ayrımcı Dil Eylül-Aralı 2014 Raporu içinde (ss. 61-105). İstanbul: Hrant Dink Vakfi.

Bauman, Z. (2016). Kapımızdaki yabancılar. İstanbul: Ayrıntı Yayınları.

Bell, P. (2001). Content analysis of visual images. T. van Leeuwen ve C. Jewitt (Ed), Handbook of Visual Analysis (ss. 10-34). Londra: Sage.

Bleiker, R., Campbell, D., Hutchison, E. ve Nicholson, X (2013). The visual dehumanisation of refugees, Australian Journal of Political Science, 48(4), 398-416.

Harrell-Bond, B. (2002). Can humanitarian work with refugees be humane?, Human Rights Quarterly, 24, 51-85.

Çakır, M. (2013). İnternet haberciliğinde yasadışı göç sorunu (Ocak 2011- Nisan 2012), Online Academic Journal of Information Technology, 4(12), 105-124.

Dağtaş, S. (2017). Whose misafirs? Negotiating difference along the Turkish-Syrian border, International Journal of Middle East Studies, 49(4), 661-679. 
Demir, O.Ö. ve Erdal, H. (2010). Yasadışı göç ile ilgili kavramların doğru anlaşılamaması sorunu ve yazılı basında çıkan haberler üzerine bir inceleme, Polis Bilimleri Dergisi, 12(1), 29-54.

Doğanay, Ü. ve Çoban Keneş, H. (2016a). Yazılı basında Suriyeli 'Mülteciler': ayrımcı söylemlerin rasyonel ve duygusal gerekçelerinin inşası, Mülkiye Dergisi, 40(1), 143-184.

Doğanay, Ü. ve Çoban Keneş, H. (2016b). Hak temelli bakış açısının yoksunluğu ve ayrımcı söylemler açısından gazete haberlerinde mülteci kadınlar. Y. İnceoğlu ve S. Çoban (Ed), Haber Okumaları içinde (ss. 253-294). İstanbul: İletişim Yayınları.

Efe, İ. (2019). A Corpus-driven analysis of representations of Syrian asylum seekers in the Turkish Press 2011-2016, Discourse \& Communication, 13(1), 48-67.

Efe, İ., Pandır, M., ve Paksoy, A.F. (2018). Algllar ve gerçekler arasında: Türk basınında Suriyeli mülteciler. Ankara: Nobel Bilimsel Eserler.

Erdoğan, M. (2020). Suriyeliler barometresi 2019: Suriyelilerle uyum içinde yaşamın çerçevesi. Ankara: Orion Kitabevi.

Erdoğan, M. (2018). Suriyeliler barometresi: Suriyelilerle uyum içinde yaşamın çerçevesi. İstanbul: Bilgi Üniversitesi Yayınlar1.

Erdoğan, M. (2015). Türkiye'deki Suriyeliler: toplumsal kabul ve uyum. İstanbul: Bilgi Üniversitesi Yayınlar1.

Friedman, E. ve Klein, R. (2008). Reluctant refugee: the story of asylum in Britain. Londra: British Library.

Göç İdaresi Genel Müdürlüğü (2020). Geçiçi koruma. https://www.goc.gov.tr/gecicikoruma5638 (Erişim tarihi: 25.11.2020).

İGAM İltica ve Göç Araştırma Merkezi (2019). Ulusal ve yerel medyada mülteci ve göç haberleri,01.06.2017-30.11.2018.

https://drive.google.com/file/d/1nKXyM266XShryaPJBix_neIWn_fGGUjQ/view (Erişim tarihi: 25.11 .2020 )

Kolukırık, S. (2009). Mülteci ve sığınmacı olgusunun medyadaki görünümü: medya politiği üzerine bir değerlendirme, Gaziantep Üniversitesi Sosyal Bilimler Dergisi. 8(1), 1-20.

Mannik, L. (2012). Public and private photographs of refugees: the problem of representation, Visual Studies, 27(3), 262-276.

Nielsen, S. Y. (2016). Perceptions between Syrian refugees and their host community, Turkish Policy Quarterly, 15(3), 99-106.

Özerim, G., Telli, M. B ve Karaca, L. (2020). Türkiye'deki genç mültecilere yönelik destek mekanizmalarının gelişstirilmesi için durum ve ihtiyaç analizi çalışması raporu. https://www.gencmulteciler.org/wp-content/uploads/2020/06/Türkiyedeki-Genç-MültecilereYönelik-Destek-Mekanizmalarının-Geliştirilmesi-İçin-Durum-ve-İhtiyaç-Analizi-ÇalışmasıRaporu.pdf (Erişim tarihi: 05.12.2020)

Paksoy, A. ve Şentöregil, M. (2018). Türk basınında Suriyeli sığınmacılar: ilk beş yılın analizi (2011-2015), Selçuk Üniversitesi İletişim Fakültesi Akademik Dergisi, 11(1), 237-256.

Pandır, M. (2020). Media portrayals of refugees and their effects on social conflict and social cohesion, Perceptions: Journal of International Affairs, 25(1), 99-120.

Pandir, M. (2019). Stereotyping, victimization and depoliticization in the representations of Syrian Refugees, Dokuz Eylül Üniversitesi Sosyal Bilimler Enstitüsü Dergisi. 21(2), 409422. 
Pandır, M. Efe, İ. ve Paksoy, A.F. (2015). Türk basınında Suriyeli sığınmacı temsili üzerine bir içerik analizi. Marmara İletişim Dergisi, 24, 1-26.

Saraçoğlu, C. Ve Bélanger, D. (2019). Loss and Xenophobia in the city: contextualizing antiSyrian sentiments in Izmir, Turkey, Patterns of Prejudice, 53(4), 363-383.

Sunata, U. ve Yildız E. (2018). Representation of Syrian refugees in the Turkish media, Journal of Applied Journalism \& Media Studies, 7(1), 129-151.

The Platform for International Cooperation on Undocumented Migrants PICUM (2020). Why words matter. https://picum.org/words-matter/ (Erişim tarihi: 24.10.2020)

van Dijk, T.A. (1991). Racism and the press. Londra: Routledge.

Yaylacı, F. G. ve Karakuş, M. (2015). Perceptions and newspaper coverage of Syrian refugees in Turkey, Migration Letters, 12(3), 238-250.

Yücebaş M (2015). Gaziantep yerel basınında Suriyeli imgesi: yeni taşranın yeni suskunları: Suriyeliler, Birikim Dergisi, 311, 38-47.

\section{ETIKK ve BİLIMSEL İLKELER SORUMLULUK BEYANI}

$\mathrm{Bu}$ çalışmanın tüm hazırlanma süreçlerinde etik kurallara ve bilimsel atıf gösterme ilkelerine riayet edildiğini yazar(lar) beyan eder. Aksi bir durumun tespiti halinde Afyon Kocatepe Üniversitesi Sosyal Bilimler Dergisi'nin hiçbir sorumluluğu olmayıp, tüm sorumluluk makale yazarlarına aittir.

\section{ARAŞTIRMACILARIN MAKALEYE KATKI ORANI BEYANI}

1. yazar katkı oranı : \%100

Bu çalışma TÜBİTAK tarafından desteklenmiştir, proje no: 115K268.

Projedeki katkılarından dolayı İbrahim Efe, Alaaddin F. Paksoy ve Erdem Selvin'e teşekkür ederim. 